\title{
Activation of Ras signaling pathways by pyrroloquinoline quinone in NIH3T3 mouse fibroblasts
}

\author{
TAKESHI KUMAZAWA ${ }^{1}$, TAKAKI HIWASA ${ }^{2}$, MASAKI TAKIGUCHI ${ }^{2}$, \\ OSAMU SUZUKI ${ }^{3}$ and KEIZO SATO ${ }^{1}$ \\ ${ }^{1}$ Department of Legal Medicine, Showa University School of Medicine, 1-5-8 Hatanodai, Shinagawa-ku, Tokyo 142-8555; \\ ${ }^{2}$ Department of Biochemistry and Genetics, Chiba University Graduate School of Medicine, Inohana 1-8-1, \\ Chuo-ku, Chiba 260-8670; ${ }^{3}$ Department of Legal Medicine, Hamamatsu University School of \\ Medicine, 1-20-1 Handayama, Hamamatsu 431-3192, Japan
}

Received December 28, 2006; Accepted February 8, 2007

\begin{abstract}
Pyrroloquinoline quinone (PQQ) has been implicated in certain physiological activities in mammals such as functioning as a potent growth factor in mice, and promoting DNA synthesis in human fibroblasts. These are clearly important physiological functions, however, the molecular mechanisms involved in PQQ activity are not yet fully understood. In order to address this, in this study we analyzed the effects of PQQ on the proliferation of NIH3T3 mouse fibroblasts and on their intracellular signal transduction mechanism. When activated c-Ha-ras-transformed NIH3T3 cells were treated with PQQ in the presence of $0.5 \%$ calf serum in DMEM, the cells showed significantly increased viability. After PQQ addition, flow cytometric analysis revealed a decrease in the population of cells in the $G_{0} / G_{1}$ phase and a concomitant increase in cells in the $S$ and $G_{2} / M$ phases. Although treatment with SNAP, an NO donor, reduced cell viability, this effect was abolished by the addition of PQQ. Activation of ERK and PKC- $\varepsilon$ was detected immediately after the addition of PQQ, and subsequent
\end{abstract}

Correspondence to: Dr Takeshi Kumazawa, Department of Legal Medicine, Showa University School of Medicine, 1-5-8 Hatanodai, Shinagawa-ku, Tokyo 142-8555, Japan

E-mail: kumazawa@med.showa-u.ac.jp

Abbreviations: CDK, cyclin/cyclin-dependent kinase; DFMO, difluoromethylornithine; ECs, endothelial cells; E2F, E2 factor; ERK, extracellular signal-regulated protein kinase; H-7, 1-(5isoquinolinesulfonyl)-2-methylpiperazine; IкB, inhibitory $\kappa \mathrm{B}$; JNK, c-Jun N-terminal kinase; MAPK, mitogen-activated protein kinase; MEK, MAPK/ERK kinase; NF-кB, nuclear factor-кB; NO, nitric oxide; NOS, nitric oxide synthase; ODC, ornithine decarboxylase; PI3K, phosphoinositide 3-kinase; PKC, protein kinase C; PQQ, pyrroloquinoline quinine; $\mathrm{Rb}$, retinoblastoma protein; $\mathrm{ROS}$, reactive oxygen species; SNAP, $S$-nitroso- $N$ - acetylpenicillamine

Key words: pyrroloquinoline quinone, cell proliferation, signal transduction increases in the phosphorylation of $\mathrm{Rb}$ and $\mathrm{c}$-Jun were observed. On the other hand, protein expression levels of growth-inhibitory molecules such as IкB and p27 decreased after PQQ treatment. These results suggest that PQQ stimulates cell proliferation through NO-sensitive Rasmediated signaling pathways.

\section{Introduction}

Pyrroloquinoline quinone (PQQ, Fig.1) was identified as a novel redox cofactor in several bacterial dehydrogenases in 1979 (1). PQQ is synthesized by a number of microorganisms and is essential for their growth (2-4). Several reports have suggested physiological and pharmacological effects of PQQ such as protection from liver damage by ethanol in rats (5), oxidation of the $N$-methyl-D-aspartate receptor redox site in rat cortical neurons (6), protection from reoxygenation injury in isolated rabbit heart (7), increase in levels of nerve growth factor in mouse astroglial cells (8), inhibition of melanogenesis in murine B16-F10 melanoma (9), and enhancement of rat sciatic nerve regeneration (10). Killgore et al (11) reported that mice fed with a PQQ-deficient diet grew poorly, suggesting a nutritional role for PQQ in mammals. Although PQQ is not synthesized in mammals, PQQ has invoked considerable interest because of its presence in human and rat tissues $(12,13)$. Recently, the first eukaryotic PQQ-dependent enzyme, 2-aminoadipic 6-semialdehyde dehydrogenase (EC 1.2.1.31), was identified, indicating that PQQ may function as a vitamin in mammals (14). However, this potential role is currently under debate (15-17).

Various quinones are involved in a number of biochemical reactions (18) including redox reactions such as the transport of electrons in the mitochondrial respiratory chain, the carboxylation of blood coagulation factors, and a variety of alkylation reactions. The exposure of rat liver epithelial cells to menadione (2-methyl-1,4-naphthoquinone, vitamin $\mathrm{K}_{3}$ ), a quinone derivative, was shown to lead to the activation of extracellular signal-regulated protein kinase (ERK) (19). ERK is well known as one of the mitogen-activated protein kinases (MAPKs) (20) and for its prominent role in controlling proliferation, differentiation and cell survival 
(21). In a previous study, we demonstrated that PQQ was effective in increasing $\left[{ }^{3} \mathrm{H}\right]$ thymidine incorporation into DNA in cultured human fibroblasts (22). Understanding the mechanism by which PQQ modulates DNA synthesis could provide critical information pertinent to cell growth and other physiological activities in mammals; however, details of the molecular mechanisms by which PQQ exerts its effects, such as the MAPK cascade, remain unclear. In the present study, we investigated the interrelationship between the effects of PQQ on cell growth and the process of cellular signaling transduction by PQQ, using activated c-Ha-ras-transformed NIH3T3 cells.

\section{Materials and methods}

Chemicals. PQQ disodium salt was obtained from Wako Pure Chemical Industries (Osaka, Japan). Difluoromethylornithine (DFMO) hydrochloride, erbstatin, genistein, 1-(5isoquinolinesulfonyl)-2-methylpiperazine (H-7) dihydrochloride and $S$-nitroso- $N$-acetylpenicillamine (SNAP) were purchased from Sigma Chemicals (St. Louis, MO, USA). Other common chemicals were of the highest purity commercially available.

Cells and culture conditions. Activated c-Ha-ras-transformed NIH3T3 (Ras-NIH3T3) cells were kindly provided by Dr Takao Sekiya (National Cancer Center Research Institute, Tokyo, Japan) (23). The Ras-NIH3T3 cells were cultured in Dulbecco's modified Eagle's medium (DMEM) supplemented with $10 \%$ calf serum and maintained in a $37^{\circ} \mathrm{C}$ humidified atmosphere containing $5 \% \mathrm{CO}_{2}$ in air.

Flow cytometry analysis. Ras-NIH3T3 cells were washed three times with PBS and treated with staining solution (50 $\mu \mathrm{g} / \mathrm{ml}$ propidium iodide, $4 \mathrm{mM}$ sodium citrate, $0.5 \mathrm{mg} / \mathrm{ml}$ RNase A and $0.1 \%$ Triton X-100) on ice for $10 \mathrm{~min}$. $\mathrm{NaCl}$ was then added to the solution to a final concentration of $0.15 \mathrm{M}$. The cells were examined by FACScan, and cell cycle distribution was analyzed by ModFit LT Software (Becton, Dickinson and Co., Franklin Lakes, NJ, USA).

Method of assessing growth effects. Logarithmically growing cells $\left(1 \times 10^{4}\right)$ were plated in each well of 96 -well plates containing various concentrations of the test compounds and then cultured for $72 \mathrm{~h}$ according to the method of Mosmann (24) as described previously (25). The culture was incubated for $4 \mathrm{~h}$ in the presence of $0.5 \mathrm{mg} / \mathrm{ml} \mathrm{MTT}$, and then the absorbance at $570 \mathrm{~nm}$ (using a reference wavelength of $655 \mathrm{~nm}$ ) was measured. The absorbance reflected the viable cell number and was reported as a percentage of the viability of the control cells.

Preparation of cell extract and Western blot analysis. RasNIH3T3 cells were grown in 6-cm tissue culture dishes and treated with the test compounds. The cells were then washed with phosphate-buffered saline (PBS) 3 times and incubated in lysis buffer $(0.5 \%$ Nonidet P-40, $20 \mathrm{mM}$ Tris-HCl, pH 7.5, $1 \mathrm{mM}$ EDTA, $1 \mathrm{mM}$ EGTA, $1 \mathrm{mM}$ phenylmethylsulfonyl fluoride, $50 \mathrm{mM}$ leupeptin, $50 \mathrm{mM}$ antipain, $50 \mathrm{mM}$ pepstatin $\mathrm{A}$ and $50 \mathrm{mM}$ acetyl-Leu-Leu-norleucinal) for $10 \mathrm{~min}$ at $4^{\circ} \mathrm{C}$.

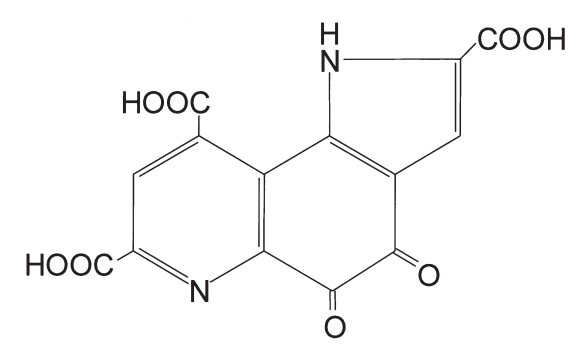

Figure 1. Chemical structure of PQQ.

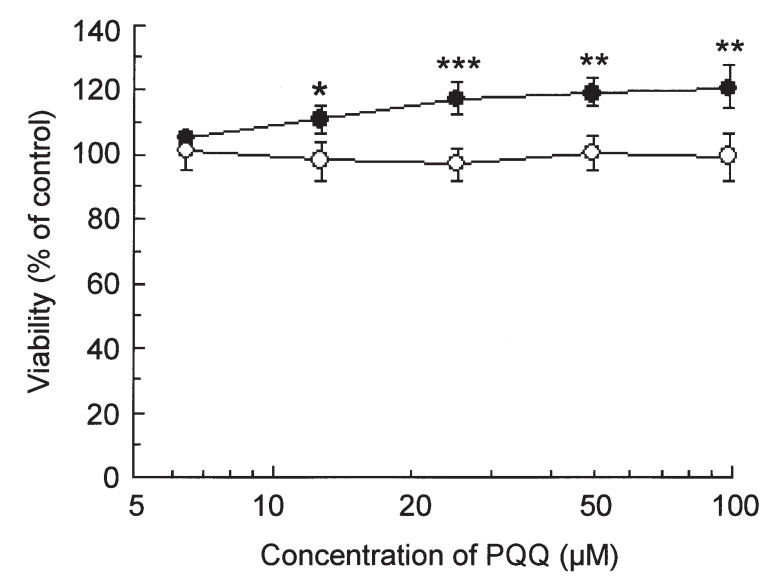

Figure 2. Effects of PQQ on proliferation of Ras-NIH3T3 cells. Cells were cultured in DMEM containing $0.5 \%(\bullet)$ or $5 \%(\odot)$ calf serum in the presence of various concentrations of PQQ for $72 \mathrm{~h}$. After incubation with MTT for $4 \mathrm{~h}$, the absorbance at $570 \mathrm{~nm}$ was measured and expressed as a percentage of that in the absence of PQQ. Data are means \pm SD (bars) of the values of 4 experiments. Asterisks indicate significant differences between 0.5 and $5 \%$ calf serum; ${ }^{*} \mathrm{p}<0.05,{ }^{* *} \mathrm{p}<0.005$ and ${ }^{* * *} \mathrm{p}<0.001$ as determined by the Student's t-test.

The cell lysate was centrifuged at 13,000 x g for $10 \mathrm{~min}$, and then the supernatant was lyophilized and used as 'cytoplasmic extract'. The pellet following centrifugation was washed once with lysis buffer, directly dissolved in SDS-sample buffer and used as 'nuclear extract'. Immunoblot analysis was carried out using Immuno-Star (Wako Pure Chemical Industries). The antibodies used were anti-phospho-specific ERK, anti-phospho-specific c-Jun, anti-phospho-specific PKC- $\varepsilon$, anti-phospho-specific Rb, anti-IкB and anti-p27.

\section{Results}

Effect of $P Q Q$ on cell viability. Ras-NIH3T3 cells were cultured with $0.5 \%$ or $5 \%$ calf serum in the presence of various concentrations of PQQ for $72 \mathrm{~h}$, and then the relative cell viability was measured by the MTT assay. The cells cultured with $0.5 \%$ calf serum showed a significant increase in cell viability at concentrations $>10 \mu \mathrm{M}$ PQQ (Fig. 2); the maximum increase in cell viability was $124 \%$ at $100 \mu \mathrm{M}$ PQQ. However, Ras-NIH3T3 cells cultured with 5\% calf serum showed no effect of PQQ on cell viability. These data suggest that the growth-promoting effects of PQQ were already active in the presence of 5\% serum but not in the presence of $0.5 \%$ serum. In preliminary experiments, normal 

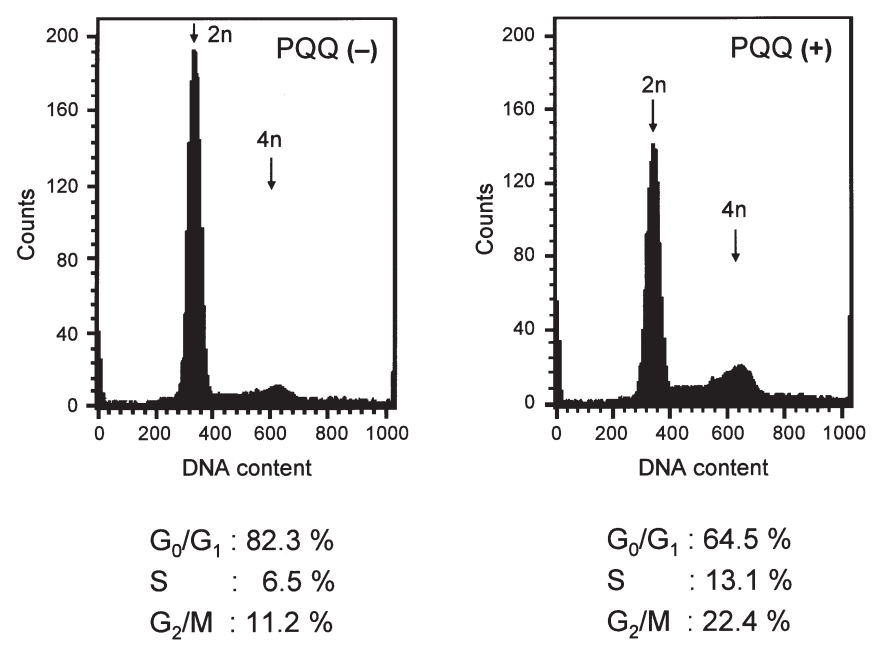

Figure 3. Flow cytometry analysis of Ras-NIH3T3 cells. Cells were cultured in DMEM containing $0.5 \%$ calf serum and $100 \mu \mathrm{M}$ PQQ for $72 \mathrm{~h}$, and analyzed using a Becton Dickinson FACScan flow cytometer.

NIH3T3 cells were cultured with 0.5 or $5 \%$ calf serum in the presence of various concentrations of PQQ for $72 \mathrm{~h}$, and then the relative viability was measured as described above; however, no significant increase in cell viability was observed (data not shown). Therefore, Ras-NIH3T3 cells were treated with $100 \mu \mathrm{M}$ PQQ in the presence of $0.5 \%$ calf serum in the following experiments.

Effects of $P Q Q$ on cell cycle progression. To determine the effects of PQQ on cell cycle progression, flow cytometric analysis was conducted on Ras-NIH3T3 cells. After $72 \mathrm{~h}$ of culture in the absence of PQQ, the cells were arrested in the $\mathrm{G}_{0} / \mathrm{G}_{1}$ phase. In contrast, in Ras-NIH3T3 cells treated with PQQ for $72 \mathrm{~h}$, the population in the $\mathrm{S}$ and $\mathrm{G}_{2} / \mathrm{M}$ phases increased from 6.5 to $13.1 \%$ and 11.2 to $22.4 \%$, respectively, with a concomitant decrease in the number of $\mathrm{G}_{0} / \mathrm{G}_{1}$ cells from 82.3 to $64.5 \%$ (Fig. 3). These results suggest that PQQ reduced $\mathrm{G}_{1}$ arrest in Ras-NIH3T3 cells.

Western blot analysis. To investigate the molecular events initiated by PQQ, cell extracts were analyzed by Western blotting with specific antibodies to a number of key signaling molecules. ERK is a typical growth-promoting molecule and is activated through phosphorylation by MAPK/ERK kinase (MEK) $(19,20,26)$. It is presently believed that protein kinase C (PKC)- $\varepsilon$ participates in serum-induced cell growth of NIH3T3 fibroblasts (27). Therefore, we first investigated the effects of PQQ on the activation of ERK and PKC- $\varepsilon$ enzymes in Ras-NIH3T3 cells using phospho-specific antibodies. The cells were incubated with PQQ for various periods. Maximal ERK activation through phosphorylation was observed after $1 \mathrm{~h}$ of PQQ treatment (Fig. 4A), and PKC- $\varepsilon$ activation was also markedly increased after $1 \mathrm{~h}$ of treatment with PQQ (Fig. 4B). Since the activation of ERK and PKC- $\varepsilon$ occurred shortly after PQQ addition, the primary target of PQQ may be closely related to these molecules. These results suggest that PQQ can promote both ERK and PKC- $\varepsilon$ activities as early events in the progression of Ras-NIH3T3 cells.

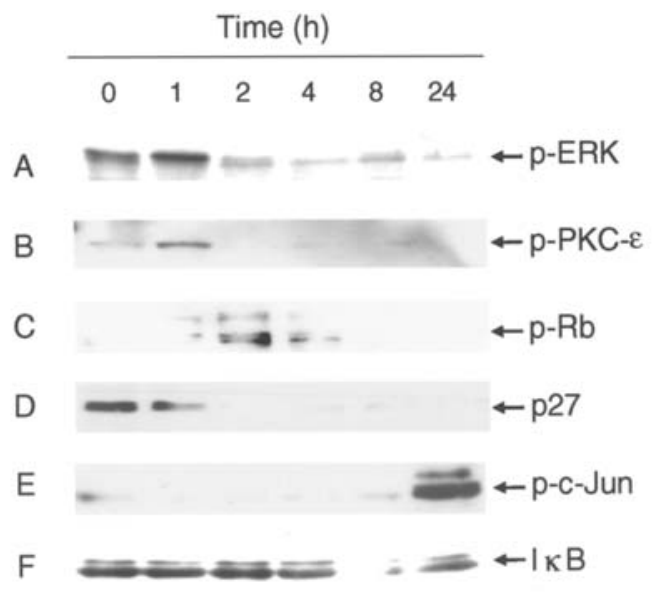

Figure 4. Effects of PQQ on signaling molecules in Ras-NIH3T3 cells. Cells were cultured in DMEM containing $0.5 \%$ calf serum for $1,2,4,8$ and $24 \mathrm{~h}$ in the presence of $100 \mu \mathrm{M}$ PQQ and then subjected to immunoblot assay with the indicated antibodies.

Retinoblastoma protein $(\mathrm{Rb})$ is a major regulator of the $\mathrm{G}_{1} / \mathrm{S}$ transition in the cell cycle (28). Phosphorylation of $\mathrm{Rb}$ results in a change in its molecular configuration, the release of bound transcription factors such as E2F, and, ultimately, progression through the cell cycle. The proteins p27 and p21 represent a family of molecules which block the activity of cyclin/cyclin-dependent kinase (CDK) complexes responsible for phosphorylation of $\mathrm{Rb}$ (29). As shown in Fig. 4C, Rb phosphorylation was induced by incubation with PQQ, reaching its highest level after $2 \mathrm{~h}$. In addition, PQQ reduced protein expression levels of p27 after 1-2 h (Fig. 4D), but had no effect on the levels of p21 (data not shown).

To assess the participation of transcription factors on the effects of PQQ, we confirmed the presence of phosphorylated c-Jun protein in Ras-NIH3T3 cells. Timecourse studies of PQQ effects showed a gradual activation of c-Jun, but a dramatic increase in c-Jun phosphorylation after $24 \mathrm{~h}$ of PQQ treatment (Fig. 4E). The activity of transcription factor $\mathrm{NF}-\mathrm{\kappa B}$ is suppressed in the cytoplasm in quiescent cells via association with IкB protein (30). However, under certain conditions during cell growth and cell-cycle progression, phosphorylation of I $\mathrm{K}$ by IкB kinase allows nuclear translocation and DNA binding of $\mathrm{NF}-\kappa \mathrm{B}$, and proteolytic degradation of IкB by the proteasome $(31,32)$. We therefore investigated the expression level of $\mathrm{I \kappa B}$ and found that an 8-h treatment with PQQ reduced IкB levels, although levels recovered completely $24 \mathrm{~h}$ after the addition of PQQ (Fig. 4F). These data suggest that PQQ affects the transcriptional activities of c-Jun and NF- $\mathrm{B}$ in Ras-NIH3T3 cells.

Effects of SNAP, DFMO, H-7, genistein and erbstatin on $P Q Q$-induced cell proliferation. We next examined the growth-promoting effects of PQQ in the presence of various drugs. More than 50 drugs were examined using the MTT method (33) and several were found to affect the activity of PQQ. Treatment of Ras-NIH3T3 cells with SNAP, an NO donor, for $24 \mathrm{~h}$ decreased cell viability to $62 \%$ of that of the control cells (Fig. 5). This SNAP-induced decrease in 


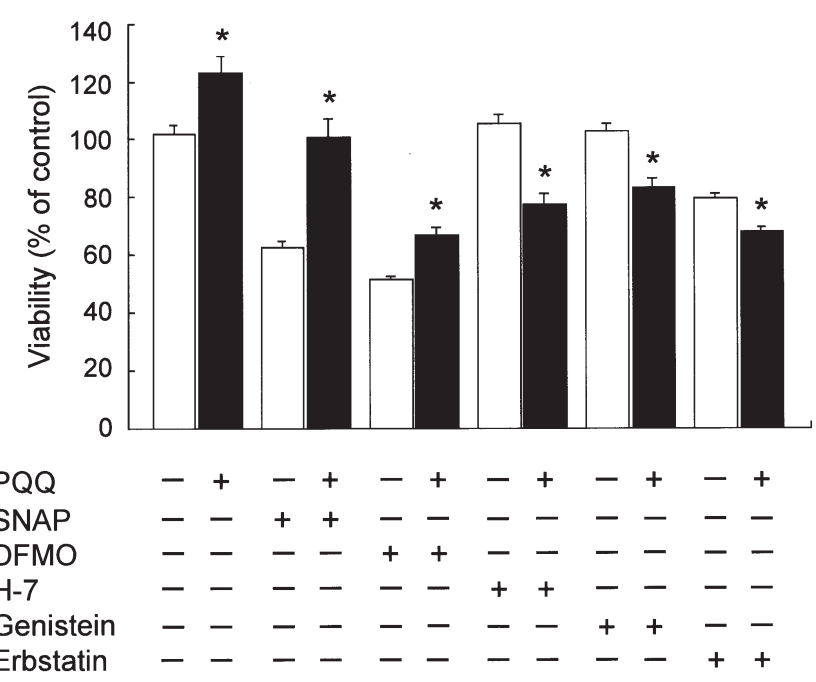

Figure 5. Effects of PQQ on cell viability of SNAP-, DFMO-, H-7-, genisteinand erbstatin-treated Ras-NIH3T3 cells. Cells were cultured in DMEM containing $0.5 \%$ calf serum in combination with 5 test compounds $(125 \mu \mathrm{M}$ SNAP, $100 \mu \mathrm{M}$ DFMO, $6 \mu \mathrm{M} \mathrm{H}-7,3 \mu \mathrm{M}$ genistein or $6 \mu \mathrm{M}$ erbstatin) for $72 \mathrm{~h}$ in the absence or presence of $100 \mu \mathrm{M}$ PQQ. The relative cell viability was examined by the MTT assay, as described in Materials and methods. PQQ was added to the cells at the same time as each of the test compounds. Data are means \pm SD (bars) of the values of 4 experiments. Asterisks indicate significant differences between treatment with and without PQQ; ${ }^{*} \mathrm{p}<0.001$ as determined by the Student's t-test.

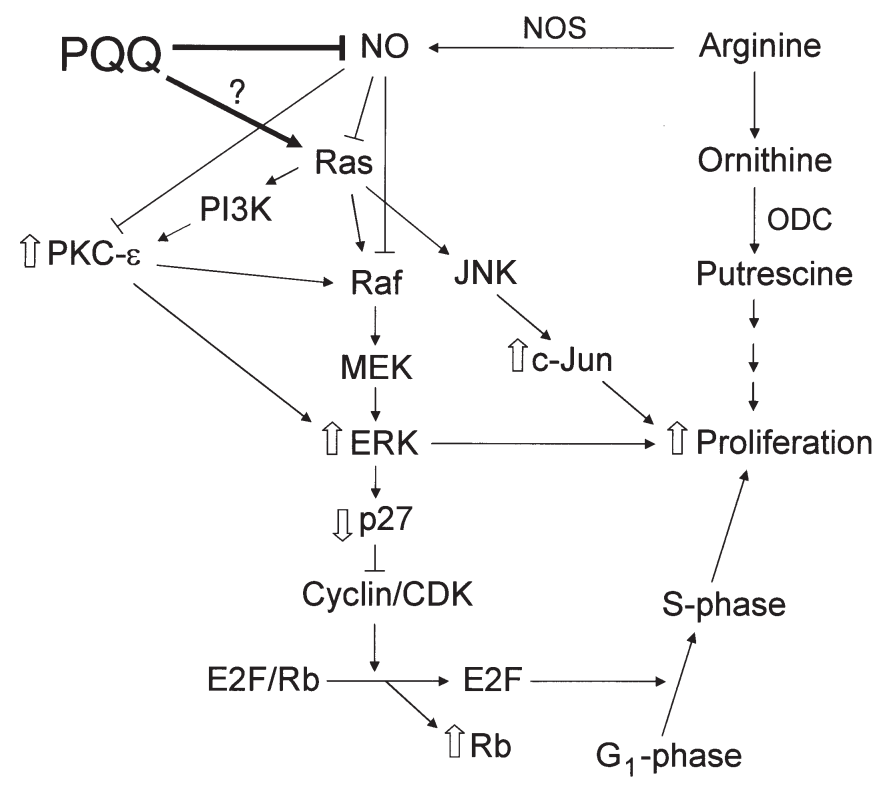

Figure 6. Schematic illustration showing the involvement of NO-sensitive Ras-mediated signaling pathways in the proliferation of Ras-NIH3T3 cells induced by PQQ. The symbols $\uparrow, \sqrt{ }, \perp$ and $\uparrow$ indicate upregulation, downregulation, inhibition and activation of signaling molecules, respectively.

viability was almost completely recovered by the addition of PQQ. Similar but incomplete recovery of viability was also observed in the presence of DFMO, an irreversible inhibitor of ornithine decarboxylase (ODC) (34). In contrast, PQQ suppressed cell proliferation in the presence of a serine/ threonine protein kinase inhibitor, $\mathrm{H}-7$ (35), and in the presence of two thyrosine kinase inhibitors, genistein and erbstatin (36) (Fig. 5). Although PQQ decreased cell viability by $\sim 28,20$ and $11 \%$, respectively, $\mathrm{H}-7$ or genistein alone did not apparently affect cell viability. These results suggest that $\mathrm{NO}$ and protein phosphorylation are involved in the PQQinduced signaling pathways.

\section{Discussion}

The major findings of the present study are that PQQ can induce cell proliferation in Ras-NIH3T3 cells, that this effect occurs via Rb-, p27-, ERK- and PKC- - -dependent mechanisms, and that PQQ protects the cells against NOinduced inhibition of cell proliferation.

The growth inhibitory protein, $\mathrm{p} 27$, plays a critical role in cell cycle regulation by virtue of its ability to respond to changes in the growth environment of a cell (37). This protein induces $G_{1}$ arrest by inhibiting specifically CDK2-mediated $\mathrm{Rb}$ phosphorylation. A decrease in $\mathrm{p} 27$ levels was observed at the early phase after addition of PQQ (Fig. 4), which is consistent not only with an increase in phosphorylated $\mathrm{Rb}$ protein but also with a decrease in the population of $\mathrm{G}_{1}$ phase cells (Fig. 3). These observations are supported by our previous study in which PQQ enhanced the incorporation of $\left[{ }^{3} \mathrm{H}\right]$ thymidine into DNA in human fibroblast cells, and in which a significant increase in $\left[{ }^{3} \mathrm{H}\right]$ thymidine incorporation was observed $24 \mathrm{~h}$ after incubation with various concentrations $(<10 \mathrm{mM})$ of PQQ. In particular, a large increase in $\left[{ }^{3} \mathrm{H}\right]$ thymidine incorporation (202-243\% of control cells) was observed at a concentration of 15-30 $\mu \mathrm{M}$ PQQ (12). In oncogenic Ras-transformed cells, p27 has been shown to be under the control of Ras-Raf-MEK-ERK signaling pathways (38). The activation of ERK leads to the downregulation of p27 production and cell cycle regulation (39). The Ras-PI3K$\mathrm{PKC}-\varepsilon$ signaling pathway is also necessary for maintenance of the Ras-transformed state (40), and PKC- $\varepsilon$ acts as a Raf activator (41). The present study revealed that prominent phosphorylation of ERK was accompanied by PKC- $\varepsilon$ phosphorylation in Ras-NIH3T3 cells exposed to PQQ for $1 \mathrm{~h}$ (Fig. 4A and B). Based on these previous observations and our current findings, it is strongly suggested that PQQ contributes to the stimulation of DNA synthesis in cell proliferation via simultaneous phosphorylation of ERK and PKC- $\varepsilon$, followed by degradation of p27 and phosphorylation of $\mathrm{Rb}$.

The downstream effectors of the MAPKs include several transcription factors, such as c-Jun, c-Fos and Elk-1 $(38,42)$. The activation of the MAPK cascade is succeeded by an increase in the expression of c-Jun and c-Fos, which form the AP-1 complex. The transcriptional activity of AP-1 is also dependent on the degree of phosphorylation of c-Jun and c-Fos, as well as their abundance. In addition, phosphorylation of c-Jun by c-Jun N-terminal kinase (JNK) is known to stimulate AP-1 transactivation activity, resulting in an enhancement of the transcription-stimulating activity of c-Jun. In the present study, we showed that PQQ induced c-Jun phosphorylation in Ras-NIH3T3 cells (Fig. 4E), suggesting that PQQ can regulate c-Jun expression through the MAPK cascade. Involvement of protein phosphorylation in PQQ-induced signaling pathways was also supported by the observation that the growthpromoting effects of PQQ were abolished by the protein kinase inhibitors H-7, genistein and erbstatin (Fig. 5). 
Reactive oxygen species (ROS) including superoxide anion, hydroxyl radical and hydrogen peroxide, and reactive nitrogen species such as NO and peroxynitrite, are biologically important oxygen derivatives that are increasingly recognized as being necessary in numerous cellular and organ functions, including inhibition of cell proliferation (43-45). It was previously reported that PQQ scavenges superoxide anion and hydroxyl radicals in cell-free in vitro experiments (46). A recent study has indicated that NO donors, such as 3morpholinosydnonimine, cause neuronal cell death in cultured rat forebrain neurons, and that PQQ can suppress peroxynitrite formation and block neurotoxicity (47). However, the detailed molecular mechanisms involved in the interaction of ROS and PQQ have not been elucidated.

Raines et al (48) reported that the production of NO inactivates Ha-Ras protein and inhibits downstream ERK; NO can directly modify the Ras protein at Cys ${ }^{118}$ by S-nitrosylation, which subsequently leads to inhibition of signaling through the ERK pathway. In this study, SNAP (125 $\mu \mathrm{M})$, an NO donor, inhibited the proliferation of Ras-NIH3T3 cells, but the effect was abolished by the addition of $100 \mu \mathrm{M}$ PQQ (Fig. 5). Thus the decrease in viability of Ras-NIH3T3 cells by SNAP might be due to inhibition of the ERK-dependent MAPK cascade, and PQQ may prevent or alleviate NOinduced inhibition of the ERK-dependent MAPK cascade. In contrast, several studies have reported that $\mathrm{PKC}-\varepsilon$ is required for fluid shear stress-mediated activation of ERK in endothelial cells (ECs) (49), and PKC- $\varepsilon$ overexpression was shown to induce sustained phosphorylation of MAPK in epidermal growth factor-treated PC12 cells (50). Similarly, PKC- $\varepsilon$ acts as a Raf activator that leads to a prolonged effect on the MAPK cascade and gene induction in ECs (41). NO and $\mathrm{PKC}-\varepsilon$ have recently been implicated in the proliferative response in ECs, whereby the generation of NO reduces the activation of $\mathrm{PKC}-\varepsilon$ (51). These observations predict that S-nitrosylation of the Ha-Ras protein in Ras-NIH3T3 cells by NO may lead to the inhibition of PKC- $\varepsilon$ and its downstream signaling molecules such as Raf and ERK, and that PQQ may then prevent their inhibition.

ODC catalyzes the conversion of ornithine to putrescine in mammalian cells, and putrescine is further converted to spermidine and spermine. It is well known that these three polyamines (putrescine, spermidine and spermine) are required for mammalian cell growth (52), and are depleted by up to 60-70\% after exposure to DFMO for $24 \mathrm{~h}$ (53). The present study revealed that DFMO reduced Ras-NIH3T3 cell viability to $51 \%$ of that of the control cells (Fig. 5), presumably due to the depletion of intercellular polyamines. It should be noted that ornithine is a substrate for the production of NO by NO synthase (NOS) (54). Thus, DFMO might also affect NO levels. Because the cytostatic effects of DFMO as well as SNAP were suppressed by PQQ (Fig. 5), it is possible that PQQ regulates intracellular NO levels.

In conclusion, this study provides the first evidence that PQQ increases cell proliferation in Ras-NIH3T3 cells via Ras-related signaling pathways such as Ras-Raf-MEK-ERK and Ras-PI3K-PCK-ع-Raf/ERK (Fig. 6). This effect of PQQ might be derived from its regulation of NO levels. The present study not only expands our knowledge of mechanotransduction in Ras-NIH3T3 cells, but also contributes to the understanding of cellular mechanisms, cell signaling and gene expression relevant to PQQ in mammals.

\section{References}

1. Salisbury SA, Forrest HS, Cruse WBT and Kennard O: A novel coenzyme from bacterial primary alcohol dehydrogenases. Nature 280: 843-844, 1979.

2. Mincy T, Bell JA, Mildvan AS and Abeles RH: Mechanism of action of methoxatin-dependent alcohol dehydrogenase. Biochemistry 20: 7502-7509, 1981.

3. Ameyama M, Matsushita K, Ohno Y, Shinagawa E and Adachi O: Existence of a novel prosthetic group, PQQ, in membrane-bound, electron transport chain-linked, primary dehydrogenases of oxidative bacteria. FEBS Lett 130: 179-183, 1981.

4. Duine JA, Frank J and Jongejan JA: Enzymology of quinoproteins. Adv Enzymol Relat Areas Mol Biol 59: 169-212, 1987.

5. Hobara N, Watanabe A, Kobayashi M, Tsuji T, Gomita Y and Araki Y: Quinone derivatives lower blood and liver acetaldehyde but not ethanol concentrations following ethanol loading to rats. Pharmacology 37: 264-267, 1988.

6. Aizenman E, Hartnett KA, Zhong C, Gallop PM and Rosenberg PA: Interaction of the putative essential nutrient pyrroloquinoline quinine with the $\mathrm{N}$-methyl-D-aspartate receptor redox modulatory site. J Neurosci 12: 2362-2369, 1992.

7. Xu F, Mack CP, Quandt KS, Shlafer M, Massey V and Hultquist DE: Pyrroloquinoline quinone acts with flavin reductase to reduce ferryl myoglobin in vitro and protects isolated heart from re-oxygenation injury. Biochem Biophys Res Commun 193: 434-439, 1993.

8. Murase K, Hattori A, Kohno M and Hayashi K: Stimulation of nerve growth factor synthesis/secretion in mouse astroglial cells by coenzymes. Biochem Mol Biol Int 30: 615-621, 1993.

9. Kosano H, Setogawa T, Kobayashi K and Nishigori H: Pyrroloquinoline quinone (PQQ) inhibits the expression of tyrosinase mRNA by $\alpha$-melanocyte stimulating hormone in murine B16 melanoma cells. Life Sci 56: 1707-1713, 1995.

10. Liu S, Li H, Yang JO, Peng H, Wu K, Liu Y and Yang J: Enhanced rat sciatic nerve regeneration through silicon tubes filled with pyrroloquinoline quinone. Microsurgery 25: 329-337, 2005.

11. Killgore J, Smidt C, Duich L, Romero-Chapman N, Tinker D, Reiser K, Melko M, Hyde D and Rucker RB: Nutritional importance of pyrroloquinoline quinine. Science 245: 850-852, 1989.

12. Kumazawa T, Seno H, Urakami T, Matsumoto T and Suzuki O: Trace levels of pyrroloquinoline quinone in human and rat samples detected by gas chromatography/mass spectrometry. Biochim Biophys Acta 1156: 62-66, 1992.

13. Suzuki $\mathrm{O}$ and Kumazawa T: Gas chromatographic-mass spectrometric analysis of pyrroloquinoline quinine. Methods Enzymol 280: 150-158, 1997.

14. Kasahara T and Kato T: Nutritional biochemistry: A new redoxcofactor vitamin for mammals. Nature 422: 832, 2003.

15. Felton LM and Anthony C: Biochemistry: role of PQQ as a mammalian enzyme cofactor? Nature 433: E10, 2005.

16. Rucker R, Storms D, Sheets A, Tchaparian E and Fascetti A: Biochemistry: is pyrroloquinoline quinone a vitamin? Nature 433: E10-E11, 2005.

17. Kasahara $\mathrm{T}$ and Kato T: Biochemistry: Is pyrroloquinoline quinone a vitamin? (Reply). Nature 433: E11-E12, 2005.

18. Bolton JL, Trush MA, Penning TM, Dryhurst G and Monks TJ: Role of quinones in toxicology. Chem Res Toxicol 13: 135-160, 2000 .

19. Lewis TS, Shapiro PS and Ahn NG: Signal transduction through MAP kinase cascades. Adv Cancer Res 74: 49-139, 1998.

20. Chang L and Karin M: Mammalian MAP kinase signaling cascades. Nature 410: 37-40, 2001.

21. Abdelmohsen K, Gerber PA, von Montfort C, Sies H and Klotz LO: Epidermal growth factor receptor is a common mediator of quinone-induced signaling leading to phosphorylation of connexin-43: role of glutathione and tyrosine phosphatases. J Biol Chem 278: 38360-38367, 2003.

22. Naito Y, Kumazawa T, Kino I and Suzuki O: Effects of pyrroloquinoline quinone (PQQ) and PQQ-oxazole on DNA synthesis of cultured human fibroblasts. Life Sci 52: 1909-1915, 1993. 
23. Sekiya T, Hirohashi S, Nishimura S and Sugimura T: Transforming activity of human melanoma DNA. Jpn J Cancer Res 74: 794-797, 1983.

24. Mosmann T: Rapid colorimetric assay for cellular growth and survival: application to proliferation and cytotoxicity assays. $\mathrm{J}$ Immunol Methods 65: 55-63, 1983.

25. Hiwasa T, Tokita H and Ike Y: Differential chemosensitivity in oncogene-transformed cells. J Exp Ther Oncol 1: 162-170, 1996.

26. Seger R and Krebs EG: The MAPK signaling cascade. FASEB J 9: 726-735, 1995.

27. Soh JW, Lee EH, Prywes R and Weinstein IB: Novel roles of specific isoforms of protein kinase $\mathrm{C}$ in activation of the c-fos serum response element. Mol Cell Biol 19: 1313-1324, 1999.

28. Dowdy SF, Hinds PW, Louie K, Reed SI, Arnold A and Weinberg RA: Physical interaction of the retinoblastoma protein with human D cyclins. Cell 73: 499-511, 1993.

29. Sherr CJ and Roberts JM: Inhibitors of mammalian G1 cyclindependent kinases. Genes Dev 9: 1149-1163, 1995.

30. Németh ZH, Wong HR, Odoms K, Deitch EA, Szabó C, Vizi ES and Haskó G: Proteasome inhibitors induce inhibitory $\kappa \mathrm{B}$ (ІкB) kinase activation, I $\mathrm{K} \mathrm{B} \alpha$ degradation, and nuclear factor $\kappa \mathrm{B}$ activation in HT-29 cells. Mol Pharmacol 65: 342-349, 2004.

31. Beg AA, Ruben SM, Scheinman RI, Haskill S, Rosen CA and Baldwin AS Jr: IкB interacts with the nuclear localization sequences of the subunits of NF- $\mathrm{B}$ : a mechanism for cytoplasmic retention. Genes Dev 6: 1899-1913, 1992.

32. Scherer DC, Brockman JA, Chen Z, Maniatis T and Ballard DW: Signal-induced degradation of IкB $\alpha$ requires site-specific ubiquitination. Proc Natl Acad Sci USA 92: 11259-11263, 1995.

33. Hiwasa T, Nakata M, Nakata M, Ohno S, Maki M, Suzuki K and Takiguchi M: Regulation of transformed state by calpastatin via PKC $\varepsilon$ in NIH3T3 mouse fibroblasts. Biochem Biophys Res Commun 290: 510-517, 2002.

34. McCann PP and Pegg AE: Ornithine decarboxylase as an enzyme target for therapy. Pharmacol Ther 54: 195-215, 1992.

35. Broberg A, Nissinen L, Potila $M$ and Heino J: Threedimensional collagen regulates collagen gene expression by a mechanism that requires serine/threonine kinases and is independent of mechanical contraction. Biochem Biophys Res Commun 280: 328-333, 2001.

36. McIntyre BS and Sylvester PW: Genistein and erbstatin inhibition of normal mammary epithelial cell proliferation is associated with EGF-receptor down-regulation. Cell Prolif 31: 35-46, 1998.

37. Rivard N, Boucher M-J, Asselin C and L'Allemain G: MAP kinase cascade is required for p27 downregulation and S phase entry in fibroblasts and epithelial cells. Am J Physiol 277: C652-C664, 1999.

38. Weinstein-Oppenheimer CR, Blalock WL, Steelman LS, Chang F and McCubrey JA: The Raf signal transduction cascade as a target for chemotherapeutic intervention in growth factorresponsive tumors. Pharmacol Ther 88: 229-279, 2000.

39. Hoshino R, Tanimura S, Watanabe K, Kataoka T and Kohno M: Blockade of the extracellular signal-regulated kinase pathway induces marked G1 cell cycle arrest and apoptosis in tumor cells in which the pathway is constitutively activated: up-regulation of p27 ${ }^{\mathrm{Kip} 1}$. J Biol Chem 276: 2686-2692, 2001.
40. Hiwasa T, Shimada H, Sakaida T, Kitagawa M, Kuroiwa N, Ochiai $\mathrm{T}$ and Takiguchi M: Drug-sensitivity pattern analysis for study of functional relationship between gene products. FEBS Lett 552: 177-183, 2003.

41. Cheng J-J, Wung B-S, Chao Y-J and Wang DL: Sequential activation of protein kinase $\mathrm{C}(\mathrm{PKC})-\alpha$ and $\mathrm{PKC}-\varepsilon$ contributes to sustained Raf/ERK1/2 activation in endothelial cells under mechanical strain. J Biol Chem 267: 31368-31375, 2001.

42. Moon H-I and Chung JH: The effect of 2',4'7-trihydroxyisoflavone on ultraviolet-induced matrix metalloproteinase-1 expression in human skin fibroblasts. FEBS Lett 580: 769-774, 2006.

43. Blachier F, Robert V, Selamnia M, Mayeur C and Duee PH: Sodium nitroprusside inhibits proliferation and putrescine synthesis in human colon carcinoma cells. FEBS Lett 396: 315-318, 1996.

44. Buga GM, Wei LH, Bauer PM, Fukuto LM and Ignarro LJ: NGhydroxy-L-arginine and nitric oxide inhibit Caco-2 tumor cell proliferation by distinct mechanisms. Am J Physiol 275: R1256-R1264, 1998.

45. Clempus RE and Griendling KK: Reactive oxygen species signaling in vascular smooth muscle cells. Cardiovasc Res 71: 216-225, 2006.

46. Urakami T, Yoshida C, Akaike T, Maeda H, Nishigori $\mathrm{H}$ and Niki E: Synthesis of monoesters of pyrroloquinoline quinine and imidazopyrroloquinoline, and radical scavenging activities using electron spin resonance in vitro and pharmacological activity in vivo. J Nutr Sci Vitaminol 43: 19-33, 1997.

47. Zhang Y and Rosenberg PA: The essential nutrient pyrroloquinoline quinine may act as a neuroprotectant by suppressing peroxynitrite formation. Eur J Neurosci 16: 1015-1024, 2002.

48. Raines KW, Cao G-L, Porsuphatana S, Tsai P, Rosen GM and Shapiro P: Nitric oxide inhibition of ERK1/2 activity in cells expressing neuronal nitric-oxide synthase. J Biol Chem 279: 3933-3940, 2004

49. Traub O, Monia BP, Dean NM and Berk BC: PKC- $\varepsilon$ is required for mechano-sensitive activation of ERK1/2 in endothelial cells. J Biol Chem 272: 31251-31257, 1997.

50. Brodie C, Bogi K, Acs P, Lazarovici P, Petrovics G, Anderson WB and Blumberg PM: Protein kinase C- $\varepsilon$ plays a role in neurite outgrowth in response to epidermal growth factor and nerve growth factor in PC12 cells. Cell Growth Differ 10: 183-191, 1999.

51. Ni C-W, Wang DL, Lien S-C, Cheng J-J, Chao Y-J and Hsieh H-J: Activation of PKC- $\varepsilon$ and ERK1/2 participates in shear-induced endothelial MCP-1 expression that is repressed by nitric oxide. J Cell Physiol 195: 428-434, 2003.

52. Pegg AE, Shantz LM and Coleman CS: Ornithine decarboxylase as a target for chemoprevention. J Cell Biochem Suppl 22: 132-138, 1995

53. Mamont PS, Duchesne M-C, Grove J and Bey P: Antiproliferative properties of DL- $\alpha$-difluoromethyl ornithine in cultured cells. A consequence of the irreversible inhibition of ornithine decarboxylase. Biochem Biophys Res Commun 81: 58-66, 1978

54. Stuehr DJ: Mammalian nitric oxide synthases. Biochim Biophys Acta 1411: 217-230, 1999 . 